\title{
PERAN KEPUASAN PELANGGAN DALAM MEMEDIASI PENGARUH KUALITAS LAYANAN TERHADAP LOYALITAS PELANGGAN (STUDI KASUS : USAHA EKSPEDISI TIKI DI KOTA DENPASAR)
}

\author{
Marcellus Ivan Novandy ${ }^{1}$ \\ Ni Made Rastini
}

\author{
${ }^{1,2}$ Fakultas Ekonomi dan Bisnis Universitas Udayana, Bali, Indonesia \\ e-mail: marcellusivan@gmail.com
}

\begin{abstract}
ABSTRAK
Tujuan penelitian ini adalah untuk menjelaskan pengaruh kualitas layanan terhadap loyalitas pelanggan yang dimediasi oleh kepuasan pelanggan. Penelitian ini dilakukan pada konsumen yang sudah pernah menggunakan jasa ekspedisi Tiki selama satu tahun terakhir yang berdomisili di Kota Denpasar. Metode yang digunakan untuk menentukan sampel adalah non-probability yaitu purposive sampling dengan ukuran sampel sebanyak 100 orang responden. Pengumpulan data dilakukan dengan menyebar kuesioner secara langsung di Kota Denpasar. Teknik analisis data yang digunakan adalah analisis faktor konfirmatori, analisis jalur (path analysis) dan uji sobel. Hasil penelitian menunjukkan bahwa kualitas layanan, kepuasan pelanggan dan loyalitas pelanggan berpengaruh positif dan signifikan terhadap keputusan penggunaan jasa ekspedisi Tiki di Kota Denpasar.
\end{abstract}

Kata Kunci: kualitas layanan, kepuasan pelanggan, loyalitas pelanggan penggunaan jasa ekspedisi

\begin{abstract}
The purpose of this study was to clarify the effect of service quality on customer loyalty mediated by customer satisfaction. The research was conducted on consumers who have been using the services Tiki expedition in the last year who live in the city of Denpasar. The method used to determine the sample is non-probability is purposive sampling with a sample size of 100 respondents. Data was collected by questionnaire directly spread in the city of Denpasar. The data analysis technique used is the confirmatory factor analysis, path analysis (path analysis) and Sobel test. The results showed that the quality of service, customer satisfaction and customer loyalty and significant positive effect on the decision to use Tiki expedition services in the city of Denpasar.
\end{abstract}

Keywords: service quality, customer satisfaction, customer loyalty services usage expedition 


\section{PENDAHULUAN}

Industri jasa telah menjadi industri yang berkembang pesat dengan menjadi salah satu industri yang mulai diminati oleh para pelaku usaha. Dalam hal ini perkembangan jasa khususnya di Indonesia telah berkembang dengan dibuktikannya banyak munculnya usaha usaha baru disektor jasa. Salah satunya ialah perkembangan usaha dalam bidang jasa eskpedisi atau kurir.

Meningkatnya mobilisasi barang dan juga teknologi akan membuat usaha jasa eskpedisi sendiri menjamur dan memiliki potensi persaingan yang cukup tinggi. Ketatnya persaingan dalam jasa ekspedisi khususnya di Indonesia semakin menuntut penyedia jasa ekspedisi agar selalu memanjakan konsumen atau pelanggan dengan memberikan pelayanan terbaik. Pelayanan jasa yang terbaik tentunya akan menjadi pilihan para pelanggan dalam mencari jasa untuk memenuhi kebutuhannya. Menurut Kotler (2002:83) pelayanan sendiri adalah setiap tindakan atau kegiatan yang dapat ditawarkan oleh suatu pihak kepada pihak lain, yang pada dasarnya tidak berwujud dan tidak mengakibatkan kepemilikan apapun, dengan adanya perusahaan jasa memberikan pelayanan yang maksimal, diharapan dapat memberikan nilai tambah yang dapat mengakibatkan kepuasan kepada konsumen sehingga akan menimbulan keloyalitasan pada konsumen.

Loyalitas sendiri adalah situasi ideal yang paling diharapkan para pemasar, dimana konsumen bersikap positif terhadap produk atau produsen (penyedia jasa) dan disertai pola pembelian ulang yang konsisten (Tjiptono, 2006). Pada hakikatnya, loyalitas pelanggan merupakan suatu hubungan antara perusahaan 
dengan pelanggan. Menurut Tjiptono (2006) loyalitas dapat diukur dengan konsumen melakukan pembelian secara berkala, kemudian konsumen tidak terpengaruh produk atau jasa yang ditawarkan oleh pihak lain dengan jenis manfaat yang sama, dan yang terakhir jasa yang diterima memuaskan konsumen, dengan terpuaskan maka pelanggan akan memberitahukan kepada pihak lain, dan sebaliknya apabila ada ketidakpuasan atas pelayanan yang diterima maka konsumen dapat memberitahukan pelayanan yang kurang memuaskan tersebut kepada pihak lain.

Perusahaan yang baik selalu menempatkan pelanggan pada pusat dari aktifitas bisnis, dari hal ini diharapkan perusahaan selalu memperhatikan dan mengutamakan pelanggan dalam segala aktifitas yang dilakukan perusahaan, sehingga konsumen menjadi pihak yang selalu di dahulukan dengan harapan akan merasa puas, nyaman, dan akhirnya menjadi loyal kepada perusahaan. Bila yang didapat sudah sesuai dengan harapan, maka proses pembelian ini terus berulang. Hal ini dapat dikatakan bahwa telah timbul keloyalan konsumen. Bila dari pengalaman yang didapat oleh konsumen tidak mendapatkan apa yang memuaskan dirinya maka konsumen tidak akan berhenti untuk mencoba merekmerek lain sampai konsumen mendapatkan produk atau jasa yang memenuhi kriteria yang mereka tetapkan. Sehingga dalam hal ini perusahaan akan berupaya untuk menjaga hubungan dengan konsumen melalui berbagai cara sehingga membuat konsumen merasa dapat dipuaskan dengan menerapkan berbagai inovasi dan kreatifitas. 
Berbagai inovasi dan kreatifitas perlu dilakukan oleh perusahaan dalam menghadapi persaingan dan perkembangan dunia bisnis, hal ini dapat dicapai dengan kepuasan yang dialami oleh pelanggan. Kepuasan pelanggan adalah suatu keadaan dimana keinginan, harapan dan kebutuhan pelanggan terpenuhi. Pelayanan dinilai memuaskan apabila pelayanan tersebut dapat memenuhi kebutuhan dan harapan pelanggan. Bowen dan Chen (2001) menyatakan bahwa kepuasan pelanggan berhubungan erat dengan loyalitas pelanggan, dalam hal ini untuk mencapai tahap loyalitas pelanggan diwajibkan merasakan kepuasan yang diberikan oleh perusahaan penyedia jasa. hal ini diharuskan agar tercipta suatu ikatan antara pelanggan dan penyedia jasa. Kepuasan konsumen sendiri juga dapat diartikan sebagai suatu keadaan dimana harapan konsumen terhadap suatu produk sesuai dengan harapan yang diterima dan kemampuan produk tersebut dapat memuaskan kebutuhan dari konsumen. Jika produk tersebut jauh dibawah harapan konsumen maka akan menimbulkan ketidak percayaan antara konsumen dengan produk. Sebaliknya jika produk tersebut memenuhi harapan konsumen, maka konsumen akan memberikan ekspetasi yang tinggi nantinya kepada produk atau perusahaan tersebut, menurut Ellitan (2006) kepuasan pelanggan adalah tidak adanya keluhan dan tidak adanya komplain dari masyarakat yang menyebabkan dampak besar kepada perusahaan dan perasaan suka serta puas terhadap keseluruhan produk yang dimiliki oleh perusahaan.

Harapan konsumen dapat diketahui dari pengalaman mereka sendiri saat menggunakan produk tersebut, omongan orang lain dan juga informasi dari media massa diharapkan dapat menimbulkan suatu loyalitas antara produk dan 
konsumen sehingga untuk mendapatkan kepuasan yang maksimal harus dilalui dengan meningkatkan kualitas layanan. Menurut Parasuraman dalam Tjiptono (2005:273), kualitas layanan dapat dilihat dari lima dimensi antara lain bukti fisik, keandalan, daya tanggap, jaminan, dan empati. Tingkat kepuasan konsumen terhadap layanan suatu perusahaan dapat dilihat dari kepuasan konsumen terhadap kelima dimensi layanan yang ditawarkan oleh perusahaan tersebut. Dimensi tersebut adalah tangibles (bukti fisik) yaitu kemampuan suatu perusahaan dalam menunjukkan eksistensinya kepada pihak eksternal. Penampilan dan kemampuan sarana dan prasarana fisik perusahaan dan keadaan lingkungan sekitarnya adalah bukti nyata dari pelayanan yang diberikan oleh pemberi jasa, yang meliputi fasilitas fisik seperti gedung dan gudang, perlengkapan dan peralatan yang dipergunakan, reliability (kehandalan) yaitu kemampuan perusahaan untuk memberikan pelayanan sesuai yang dijanjikan secara terpercaya serta konsistensi dalam bekerja, responsiveness (ketanggapan) yaitu kemauan untuk membantu dan memberikan pelayanan yang cepat dan tepat kepada pelanggan, dengan penyampaian informasi yang jelas, assurance (jaminan dan kepastian) yaitu rasa aman yang diberikan perusahaan dari segi keamanan maupun kerahasiaan kepada pelanggan, emphaty (empati) yaitu memberikan perhatian yang tulus dan bersifat individual atau pribadi yang diberikan kepada para pelanggan dengan berupaya memahami keinginan konsumen. Dimana suatu perusahaan diharapkan memiliki pengertian dan pengetahuan tentang pelanggan, memahami kebutuhan pelanggan secara spesifik, serta memiliki waktu untuk pengoperasian yang nyaman bagi pelanggan. Pelanggan yang mengalami kegagalan pelayanan yang diterimanya, 
cenderung akan memberikan informasi yang negatif kepada orang lain terhadap jasa tersebut (Mattila dalam Sutomo, 2012).

Penelitian ini dilakukan pada usaha Tiki di Kota Denpasar. Tiki sendiri memfokuskan penjualan dan melayani target pasar yaitu konsumen atau masyarakat yang ingin mengirim barang dengan aman dan juga cepat. Akan tetapi kondisi Tiki dalam beberapa bulan terakhir mengalami penurunan jumlah pelanggan apabila dilihat dari faktor penerimaan brand oleh masyarakat.Tabel 1. menunjukkan tingkat Top Brand yang dimiliki Tiki yang mengalami penurunan dibandingkan kompetitornya.

Tabel 1.

Jasa Kurir Top Brand 2013-2016

\begin{tabular}{ccccc}
\hline \multicolumn{5}{c}{ Jasa Kurir Top Brand 2013-2016 } \\
\hline Merek & Th 2013(\%) & Th 2014 (\%) & Th 2015 (\%) & Th 2016 (\%) \\
Tiki & 53.70 & 45.10 & 36.2 & 35.7 \\
Jne & 28.60 & 33.20 & 43.5 & 47.6 \\
Pos Indonesia & 8.40 & 8.0 & 6.7 & 9.6 \\
Lainnya & 7.7 & 13.7 & 13.6 & 7.1 \\
Total Persentase & 100 & 100 & 100 & 100 \\
\hline
\end{tabular}

Sumber :(topbrand-award.com,diunduh 14 Januari 2017)

Berdasarkan Tabel 1. terjadi fluktuasi keunggulan brand dari Tiki dari tahun 2013-2016 mengalami penurunan, namun dapat diketahui bahwa selama tahun tersebut jumlah kompetitor dari Tiki cenderung stabil dan hanya Jne mengalami peningkatan. Berdasarkan latar belakang permasalahan yang telah dibahas serta hasil dari beberapa studi terdahulu, maka penelitian ini akan meneliti pengaruh peran kepuasan pelanggan memediasi pengaruh kualitas layanan terhadap loyalitas pelanggan pada usaha jasa ekspedisi Tiki di Kota Denpasar. 
$\mathrm{H}_{1}$ : Kepuasan pelanggan berpengaruh positif dan signifikan terhadap loyalitas pelanggan

Penelitian yang dilakukan oleh Suryanto L. FX Sugiyanto dan Sugiarti (2002) membuktikan bahwa kualitas layanan berpengaruh positif dan signifikan terhadap kepuasan pelanggan. Penelitian lain yang dilakukan oleh Chich-Jen Shieh (2006) mengenai hubungan kualitas layanan dengan kepuasan pelanggan membuktikan bahwa adanya hubungan yang positif diantara keduanya. Demikian pula, Siddiqi (2011) mengatakan bahwa kualitas layanan memiliki pengaruh positif dan signifikan terhadap kepuasan pelanggan.

$\mathrm{H}_{2}$ : Kepuasan pelanggan berpengaruh positif dan signifikan terhadap loyalitas pelanggan

Bowen dan Chen (2001) menyatakan bahwa kepuasan pelanggan berhubungan erat dengan loyalitas pelanggan, dimana pelanggan yang terpuaskan akan menjadi pelanggan yang loyal. Pelanggan yang loyal akan menjadi tenaga pemasaran yang baik bagi perusahaan dengan memberikan rekomendasi dan informasi positif kepada calon pelanggan lain. Lin dan Wang (2006) menyatakan bahwa hubungan antara kepuasan dengan loyalitas adalah saat dimana konsumen merasakan kepuasan pada titik tertinggi yang melibatkan emosional dan sikap. Menurut Arab et al. (2012) dalam penelitiannya menunjukkan bahwa kualitas layanan berpengaruh positif dan signifikan terhadap loyalitas pelanggan.

$\mathrm{H}_{3}$ : Kualitas layanan berpengaruh positif dan signifikan terhadap loyalitas pelanggan 
Gautama (2012) menyatakan bahwa kualitas layanan berpengaruh terhadap loyalitas pelanggan, sehingga dapat meningkatkan jumlah pelanggan yang sudah ada. Cornelia (2008) dalam penelitiannya menyebutkan bahwa hasil penilaian konsumen atas kualitas layanan akan membentuk pola loyalitas konsumen yang apabila kualitas layanan ditingkatkan maka akan berpengaruh signifikan terhadap loyalitas pelanggan, disisi lain Delgado dan Munuera (2001) dalam penelitiannya mengemukakan bahwa ketika konsumen menerima kualitas pelayanan yang lebih baik dari biaya yang dikeluarkannya, mereka percaya menerima nilai yang sangat baik (good value), dimana hal ini akan meningkatkan loyalitasnya kepada penyedia jasa.

$\mathrm{H}_{4}$ : Kepuasan pelanggan mampu memediasi secara positif dan signifikan pengaruh kualitas pelayanan terhadap loyalitas pelanggan.

Penelitian yang dilakukan oleh Stank et al. dalam Bloemer dan Kasper (1995) menunjukkan bahwa kualitas pelayanan mempunyai pengaruh positif dan signifikan secara tidak langsung terhadap loyalitas pelanggan melalui mediasi kepuasan pelanggan. Penelitian yang dikemukakan oleh Hygid Starini (2013) menyatakan bahwa pengaruh kualitas pelayanan terhadap loyalitas konsumen dengan kepuasan sebagai variabel mediasi mempunyai pengaruh yang positif dan juga signifikan. Penelitian dari Malik (2012) juga menunjukkan hasil yang sama yaitu kepuasan pelanggan berpengaruh positif dan signifikan dalam memediasi pengaruh kualitas layanan dengan loyalitas pelanggan. 


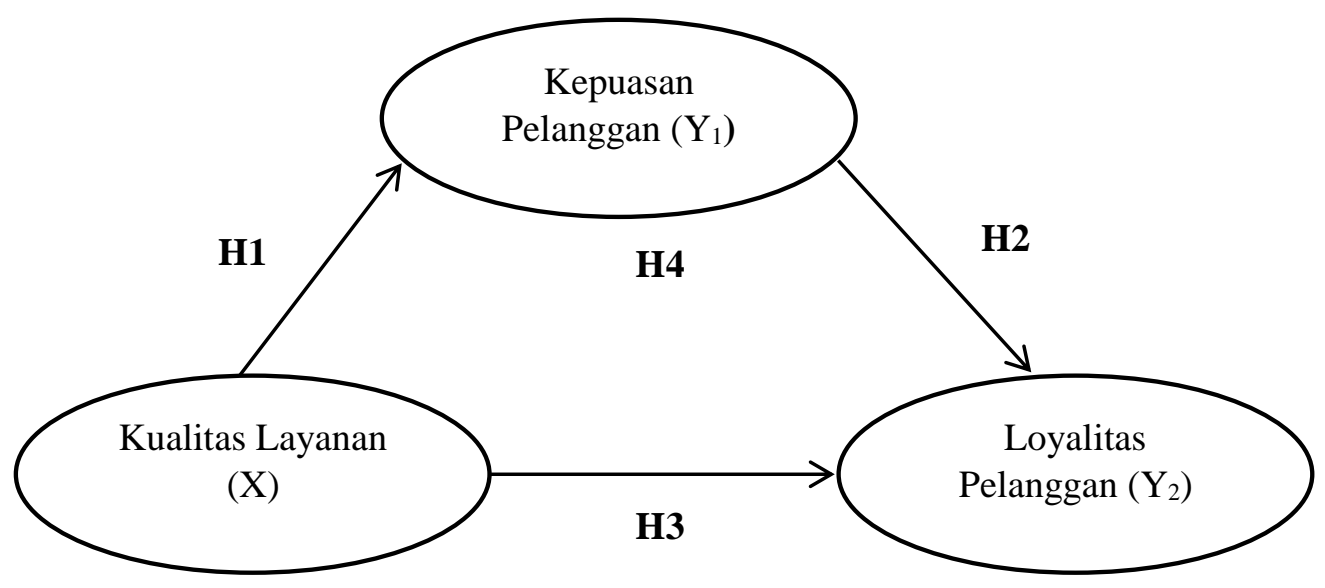

\section{Gambar 1.}

Kerangka Konsep Penelitian

\section{METODE PENELITIAN}

Penelitian ini menggunakan pendekatan kuantitatif dan merupakan penelitian asosiasif. Penelitian asosiasif merupakan penelitian yang bertujuan untuk mencari tahu hubungan atau pengaruh dari satu variabel atau lebih (Rahyuda dkk, 2004:17). Objek yang menjadi kajian dalam penelitian ini adalah kepuasan pelanggan, kualitas layanan dan loyalitas pelanggan. Populasi dalam penelitian adalah semua pengguna jasa ekspedisi Tiki di Kota Denpasar. Sampel sebanyak 100 responden, yang ditentukan dengan teknik purposive sampling. Metode pengumpulan data adalah dengan menyebarkan kuesioner, sementara analisis yang dipergunakan adalah faktor konfirmatori, analisis jalur dan uji sobel. Adapun variabel eksogen dalam penelitian ini adalah kualitas layanan (X), variabel mediasi pada penelitian ini adalah kepuasan pelanggan $\left(\mathrm{Y}_{1}\right)$, sedangkan variabel endogen pada penelitian ini adalah loyalitas pelanggan $\left(\mathrm{Y}_{2}\right)$. 
Loyalitas pelanggan berhubungan dengan komitmen pelanggan terhadap suatu merek, atau perusahaan berdasarkan sifat yang sangat positif dan dalam pembelian jangka panjang (Tjiptono, 2000). Griffin (2003:113) menyatakan bahwa loyalitas pelanggan sebagai berikut "when a customer is loyal, he or she exhibits purchase behavior defined as non-random purchase expressed over time by some decision-making it". Dalam mencari tahu apakah pelanggan yang dimiliki oleh perusahaan merupakan pelanggan yang loyal atau tidak, ada beberapa indikator yang dapat digunakan. Menurut Aaker (1991) loyalitas memiliki indikator dalam pengukurannya yaitu, satisfaction, habitual behavior, switching cost, liking of the brand, dan commitment, sedangkan Menurut Tjiptono dan Chandra (2011) loyalitas memiliki indikator yaitu, penggunaan secara berulang barang atau produk yang digunakan, pelanggan tetap memilih barang atau produk yang digunakan, merekomendasikan kepada orang sekitar, dan menyatakan hal positif terhadap barang atau produk yang digunakan.

Kotler (1997:36) menyatakan bahwa kepuasan pelanggan adalah tingkat perasaan seseorang setelah membandingkan kinerja produk yang ia rasakan dengan harapannya, jadi tingkat kepuasan merupakan fungsi dari kesan kinerja dan harapan. Pelanggan tidak akan puas jika kinerja dibawah harapan. Pelanggan akan puas jika kinerja sesuai dengan harapan. Oliver (1999) mengatakan bahwa kepuasan pelanggan merupakan bagian dari pemasaran dan mempunyai peran yang sangat vital di dalam pasar. Menurut Ellitan (2006) Kepuasan pelanggan memiliki indikator keberhasilan dalam pengukurannya yaitu, tidak ada keluhan, 
perasaan puas pelanggan, dan kesesuaian dengan ekspektasi. Sedangkan menurut Kotler (1997:42) indikator dari kepuasan pelanggan yaitu, harga, kualitas pelayanan dan kualitas produk.

Pelayanan adalah setiap tindakan atau kegiatan yang dapat ditawarkan oleh suatu pihak kepada pihak lain, yang pada dasarnya tidak berwujud dan tidak mengakibatkan kepemilikan apapun (Kotler 2002:83). Tjiptono (2007) menyatakan kualitas pelayanan adalah segala bentuk aktivitas yang dilakukan oleh perusahaan guna memenuhi harapan konsumen. Perusahaan yang memiliki layanan yang superior akan dapat memaksimalkan performa keuangan perusahaan (Gilbert et al., 2004). Zeithaml dan Bitner (1996:118) merangkum lima dimensi pokok dari kualitas layanan yang terdiri dari tangible, reliability, responsiveness, assurance, dan empathy.

\section{HASIL DAN PEMBAHASAN}

Tabel 2.

Karakteristik Responden

\begin{tabular}{|c|c|c|c|c|}
\hline No & Kategori & Klasifikasi & $\begin{array}{c}\text { Jumlah } \\
\text { (Responden) }\end{array}$ & $\begin{array}{c}\text { Persentase } \\
(\%)\end{array}$ \\
\hline \multirow{3}{*}{1} & \multirow{3}{*}{$\begin{array}{r}\text { Jenis Kelamin } \\
\text { Jumlah }\end{array}$} & Laki-Laki & 40 & 40 \\
\hline & & Perempuan & 60 & 60 \\
\hline & & & 100 & 100 \\
\hline \multirow{5}{*}{2} & \multirow{4}{*}{$\begin{array}{c}\text { Pendidikan } \\
\text { Terakhir }\end{array}$} & SMP & 12 & 12 \\
\hline & & SMA & 51 & 51 \\
\hline & & Sarjana & 35 & 35 \\
\hline & & Pascasarjana & 2 & 2 \\
\hline & Jumlah & & 100 & 100 \\
\hline \multirow{4}{*}{3} & \multirow{3}{*}{ Pekerjaan } & Mahasiswa/Pelajar & 44 & 44 \\
\hline & & $\begin{array}{c}\text { PNS/Pegawai } \\
\text { Swasta }\end{array}$ & 27 & 27 \\
\hline & & Wiraswasta & 29 & 29 \\
\hline & Jumlah & & 100 & 100 \\
\hline
\end{tabular}

Sumber : Data Primer Diolah, 2017

Tabel 2. menunjukkan bahwa pada kriteria jenis kelamin responden perempuan 20 persen lebih banyak dibandingkan responden laki-laki yaitu sebesar 
60 persen sedangkan untuk laki-laki sebesar 40 persen. Ditinjau dari kriteria kedua, responden berpendidikan terakkhir SMP sebesar 12 persen, pendidikan terakhir SMA jauh lebih banyak yaitu sebesar 51 persen, lalu pendidikan terakhir sarjana 35 persen, dan terakhir pascasarja yaitu sebesar 2 persen. Hasil dari kriteria kedua ini dapat diartikan bahwa seluruh responden telah memenuhi syarat pengisian responden yaitu minimal sudah menamatkan pendidikan SMP. Ditinjau dari kriteria ketiga, jumlah responden yang sudah berkerja lebih banyak dibandingkan responden yang masih menempuh pendidikan sebagai mahasiswa yaitu sebesar 56 persen, jadi dari kriteria ketiga ini dapat diartikan bahwa pengguna jasa Tiki tidak hanya ada di kalangan pelajar namun juga memiliki pasar dikalangan orang yang sudah berkerja.

Tabel 3.

Hasil Uji Validitas

\begin{tabular}{cccc}
\hline Variabel & Indikator & $\begin{array}{c}\text { Koefisien } \\
\text { Korelasi }\end{array}$ & Keterangan \\
\hline \multirow{6}{*}{ Kualitas Layanan } & X1.1 & 0,873 & Valid \\
& X1.2 & 0,859 & Valid \\
& X2.3 & 0,883 & Valid \\
& X2.2 & 0,780 & Valid \\
& X2.3 & 0,813 & Valid \\
& X3.1 & 0,860 & Valid \\
& X3.2 & 0,839 & Valid \\
& X4.1 & 0,893 & Valid \\
& X4.2 & 0,830 & Valid \\
Kepuasan & X5.1 & 0,941 & Valid \\
Pelanggan & Y 5.2 & 0,833 & Valid \\
& Y1.1 & 0,899 & Valid \\
\hline \multirow{2}{*}{ Loyalitas Pelanggan } & Y1.3 & 0,899 & Valid \\
& Y2.1 & 0,810 & Valid \\
& Y2.2 & 0,924 & Valid \\
\hline Y2.3 & Y2.4 & 0,850 & Valid \\
& & 0,800 & Valid \\
& & 0,864 & Valid \\
\hline
\end{tabular}

Sumber : Data Diolah, 2017

Tabel 3. menunjukkan bahwa nilai koefisien korelasi dari masing-masing instrumen menunjukkan nilai yang lebih besar dari 0,3 maka dapat dinyatakan 
bahwa seluruh instrumen dari masing-masing variabel yaitu kualitas layanan, kepuasan pelanggan, dan loyalitas pelanggan telah memenuhi syarat validitas data.

Tabel 4.

Hasil Uji Reliabilitas

\begin{tabular}{clcc}
\hline No & \multicolumn{1}{c}{ Variabel } & $\begin{array}{c}\text { Cronbach } \\
\text { Alpha }\end{array}$ & Keterangan \\
\hline 1 & Kualitas Layanan & 0,918 & Reliabel \\
2 & Kepuasan Pelanggan & 0,849 & Reliabel \\
3 & Loyalitas Pelanggan & 0,839 & Reliabel \\
\hline
\end{tabular}

Sumber : Data Diolah, 2017

Tabel 4. menunjukkan bahwa seluruh variabel memiliki nilai cronbachalpha yang lebih besar dari 0,6. Sehingga, dapat dinyatakan bahwa seluruh variabel yang digunakan dalam penelitian ini telah mampu memenuhi syarat konsistensi maupun keandalan data.

Tabel 5.

Penilaian Responden Terhadap Kulitas Layanan

\begin{tabular}{|c|c|c|c|}
\hline No & Indikator & Rata-rata & Kriteria \\
\hline \multicolumn{4}{|c|}{ Tangible } \\
\hline 1 & Tidak terdapatnya sampah diruang tunggu & 3,04 & $(\mathrm{~N})$ \\
\hline 2 & $\begin{array}{l}\text { Penampilan karyawan Tiki dalam berpakaian seragam } \\
\text { selalu rapi }\end{array}$ & 3,20 & $(\mathrm{~N})$ \\
\hline 3 & $\begin{array}{l}\text { Tiki memiliki banyak pilihan paket pengiriman barang } \\
\text { sehingga memudahkan pelanggan dalam menggunakan } \\
\text { jasa }\end{array}$ & 3,40 & $(\mathrm{~S})$ \\
\hline & Rata-rata & 3,21 & $(\mathbf{N})$ \\
\hline \multicolumn{4}{|c|}{ Reliable } \\
\hline 4 & Karyawan Tiki memberikan pelayanan dengan cepat & 3,19 & $(\mathrm{~N})$ \\
\hline 5 & $\begin{array}{l}\text { Pengiriman barang yang dilakukan Tiki sesuai dengan } \\
\text { waktu yang dijanjikan }\end{array}$ & 3,56 & $(\mathrm{~S})$ \\
\hline 6 & $\begin{array}{l}\text { Jam kerja operasional Tiki sudah sesuai dengan waktu } \\
\text { yang dikomunikasikan }\end{array}$ & 3,58 & $(\mathrm{~S})$ \\
\hline & Rata-rata & 3,44 & $(\mathbf{S})$ \\
\hline \multicolumn{4}{|c|}{$\begin{array}{l}\text { Responsiveness } \\
\end{array}$} \\
\hline 7 & $\begin{array}{l}\text { Karyawan Tiki tanggap dalam mengatasi masalah } \\
\text { dengan pelanggan }\end{array}$ & 3,60 & $(\mathrm{~S})$ \\
\hline 8 & $\begin{array}{l}\text { Karyawan Tiki tidak menunjukan kesan sibuk dalam } \\
\text { menyambut pelanggan }\end{array}$ & 3,69 & $(\mathrm{~S})$ \\
\hline \multicolumn{3}{|c|}{ Assurance } & (S) \\
\hline 9 & $\begin{array}{l}\text { Assurance } \\
\text { Tiki memberikan jaminan jika pengiriman bermasalah } \\
\text { akan mendapatkan garansi }\end{array}$ & 3,69 & $(\mathrm{~S})$ \\
\hline
\end{tabular}




\begin{tabular}{|c|c|c|c|}
\hline 10 & $\begin{array}{l}\text { Tiki menjaga kerahasiaan data para pelanggan dengan } \\
\text { benar } \\
\text { Rata-rata }\end{array}$ & $\begin{array}{l}3,46 \\
\mathbf{3 , 5 8}\end{array}$ & $\begin{array}{l}\text { (S) } \\
(\mathbf{S})\end{array}$ \\
\hline \multicolumn{4}{|c|}{ Emphaty } \\
\hline 11 & $\begin{array}{l}\text { Karyawan Tiki memberikan perhatian bersifat pribadi } \\
\text { terhadap keluhan yang disampaikan pelanggan }\end{array}$ & 3,77 & (S) \\
\hline \multirow[t]{3}{*}{12} & $\begin{array}{l}\text { Karyawan Tiki selalu mengucapkan salam pada setiap } \\
\text { pelayanan }\end{array}$ & 3,21 & $(\mathrm{~N})$ \\
\hline & Rata-rata & 3,49 & (S) \\
\hline & Rata-rata total & 3,47 & (S) \\
\hline
\end{tabular}

Sumber : Data Diolah, 2017

Tabel 5. Menunjukkan bahwa dari dimensi tangible sampai dengan dimensi emphaty menunjukkan rata-rata penilaian responden berada diatas angka 3,21. Apabila hasil ini disesuaikan dengan interval yang berada pada deskripsi penelitian maka sebagian besar responden setuju dengan apa yang dinyatakan pada pernyataan didalam kuisioner. Rata-rata dari penilaian responden terhadap variabel kualitas layanan memperoleh angka sebesar 3,47 yang masuk kedalam kriteria (S). Hasil ini memiliki arti bahwa responden setuju jika kualitas layanan yang dilakukan oleh Tiki menarik minat para responden untuk menggunakan jasa ekspedisinya.

Tabel 6.

Penilaian Responden terhadap Variabel Kepuasan Pelanggan

\begin{tabular}{clcc}
\hline No & \multicolumn{1}{c}{ Indikator } & Rata-rata & Kriteria \\
\hline 1 & $\begin{array}{l}\text { Biaya pengiriman barang yang ditetapkan } \\
\text { Tiki dirasa cukup murah }\end{array}$ & 3,24 & (N) \\
& $\begin{array}{l}\text { Barang yang dikirimkan oleh Tiki dapat } \\
\text { mudah dilacak keberadaannya oleh } \\
\text { pelanggan }\end{array}$ & 3,87 & (S) \\
3 & $\begin{array}{l}\text { Barang yang dikirimkan oleh Tiki sampai } \\
\text { tanpa adanya kecacatan barang }\end{array}$ & 3,72 & (S) \\
$\quad$ Rata-rata & $\mathbf{3 , 6 1}$ & (S)
\end{tabular}

Sumber : Data Diolah, 2017 
Tabel 6. menunjukkan penilaian responden terhadap indikator-indikator dari variabel kepuasan pelanggan. Indikator pertama mendapatkan penilaian 3,24 yang apabila kita sesuaikan dengan interval kelas maka indikator ini mendapatkan kriteria $(\mathrm{N})$, untuk indikator kedua dan ketiga mendapatkan penilaian sebesar 3,87 dan 3,72 dengan kriteria (S). Rata-rata dari penilaian responden terhadap variabel kepuasan pelanggan memperoleh angka sebesar 3,61 yang masuk kedalam kriteria (S). Hasil ini memiliki arti bahwa responden setuju jika Tiki memiliki mampu membangun kepuasan pelanggan yang baik didalam pikiran responden.

\section{Tabel 7.}

Penilaian Responden terhadap Variabel Loyalitas Pelanggan

\begin{tabular}{clcc}
\hline No & \multicolumn{1}{c}{ Indikator } & Rata-rata & Kriteria \\
\hline 1 & $\begin{array}{l}\text { Saya akan terus menggunakan jasa Tiki di } \\
\text { masa yang akan dating }\end{array}$ & 3,40 & $(\mathrm{~S})$ \\
& $\begin{array}{l}\text { Saya akan tetap menggunakan Tiki } \\
\text { walaupun terdapat kompetitor yang lebih } \\
\text { baik dari Tiki }\end{array}$ & 3,93 & $(\mathrm{~S})$ \\
& $\begin{array}{l}\text { Saya memberikan rekomendasi kepada } \\
\text { orang terdekat saya untuk menggunakan jasa } \\
\text { Tiki }\end{array}$ & 3,57 & \\
& $\begin{array}{l}\text { Saya akan terus menyatakan hal hal positif } \\
\text { mengenai Tiki }\end{array}$ & 3,36 & $(\mathrm{~S})$ \\
& $\quad$ Rata-rata & $\mathbf{3 , 5 7}$ & (N) \\
\hline
\end{tabular}

Sumber : Data Diolah, 2017

Tabel 7. menunjukkan penilaian responden terhadap indikator-indikator yang digunakan untuk mengukur pengaruh variabel loyalitas pelanggan. Indikator pertama sampai dengan indikator ketiga menunjukkan rata-rata penilaian diatas 3,57 yang apabila kita sesuaikan dengan interval kelas indikator-indikator ini berada pada kriteria (S). Indikator keempat menunjukan penilaian 3,36 yang apabila disesuaikan dengan interval kelas indikator ini berada pada kriteria $(\mathrm{N})$. Rata-rata dari penilaian responden terhadap variabel loyalitas pelanggan 
memperoleh angka sebesar 3,57 yang masuk kedalam kriteria (S). Hasil ini memiliki arti bahwa responden setuju jika setelah menggunakan jasa ekspedisi Tiki, mereka akan menggunakan kembali.

\section{Tabel 8.}

Hasil Uji KMO Variabel Penelitian

\begin{tabular}{clc}
\hline No. & \multicolumn{1}{c}{ Variabel } & Nilai KMO \\
\hline 1. & Kualitas Layanan $(\mathrm{X})$ & 0,886 \\
2. & Kepuasan Pelanggan $\left(\mathrm{Y}_{1}\right)$ & 0,682 \\
3. & Loyalitas Pelanggan $\left(\mathrm{Y}_{2}\right)$ & 0,788
\end{tabular}

Sumber : Data Diolah, 2017

Disajikan pada Tabel 8. bahwa nilai KMO pada ketiga variabel tersebut > 0,5 dan dapat disimpulkan bahwa ketiga variabel memiliki kecukupan sampel untuk analisis faktor.

Tabel 9.

Hasil Uji MSA Variabel Penelitian

\begin{tabular}{ccc}
\hline Variabel & Indikator & Nilai MSA \\
\hline & $\mathrm{X}_{1.1}$ & 0,668 \\
& $\mathrm{X}_{1.2}$ & 0,675 \\
& $\mathrm{X}_{1.3}$ & 0,736 \\
& $\mathrm{X}_{2.1}$ & 0702 \\
Kualitas Layanan & $\mathrm{X}_{2.2}$ & 0,655 \\
$(\mathrm{X})$ & $\mathrm{X}_{2.3}$ & 0,619 \\
& $\mathrm{X}_{3.1}$ & 0,500 \\
& $\mathrm{X}_{3.2}$ & 0,500 \\
& $\mathrm{X}_{4.1}$ & 0,500 \\
& $\mathrm{X}_{4.2}$ & 0,500 \\
& $\mathrm{X}_{5.1}$ & 0,500 \\
Kepuasan Pelanggan & $\mathrm{X}_{5.2}$ & 0,500 \\
$\left(\mathrm{Y}_{1}\right)$ & $\mathrm{Y}_{1.1}$ & 0,666 \\
& $\mathrm{Y}_{1.2}$ & 0,747 \\
& $\mathrm{Y}_{1.3}$ & 0,654 \\
\hline \multirow{2}{*}{ Loyalitas Pelanggan } & $\mathrm{Y}_{2.1}$ & 0,797 \\
$\left(\mathrm{Y}_{2}\right)$ & $\mathrm{Y}_{2.2}$ & 0,794 \\
& $\mathrm{Y}_{2.3}$ & 0,798 \\
& $\mathrm{Y}_{2.4}$ & 0,766 \\
\hline
\end{tabular}

Sumber : Data Diolah, 2017

Tabel 9. menunjukkan nilai MSA yang tersaji dalam Tabel untuk masingmasing variabel, menunjukkan bahwa seluruhnya bernilai $>0,50$ sehingga dapat 
disimpulkan bahwa masing-masing model dalam penelitian layak digunakan dalam analisis faktor.

Tabel 10.

Nilai Percentage of Variance Variabel Penelitian

\begin{tabular}{lccl}
\hline No. & & Variabel & Percentage of Variance \\
\hline 1. & $\mathrm{X}$ & Kualitas Layanan & 75,446 \\
2. & $\mathrm{Y}_{1}$ & Kepuasan Pelanggan & 67,641 \\
3. & $\mathrm{Y}_{2}$ & Loyalitas Pelanggan & 63,264 \\
\hline
\end{tabular}

Sumber : Data Diolah, 2017

Tabel 10. dapat dilihat bahwa nilai Percentage of Variance yang dimiliki oleh masing-masing variabel telah mampu melampaui nilai 60\%. Maka dari itu, seluruh variabel dalam penelitian ini telah mampu menjelaskan variasinya.

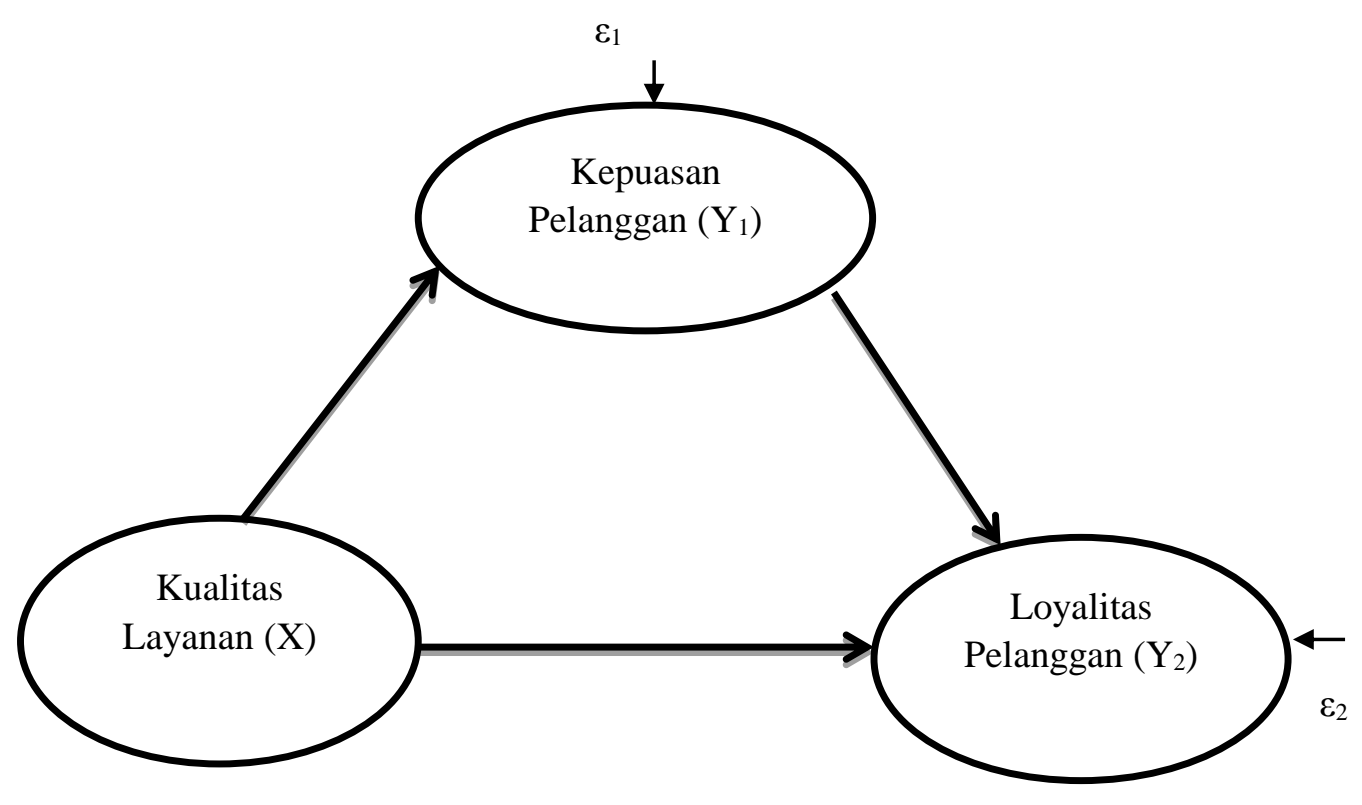

Gambar 2.

Model Analisis Pengaruh Kualitas Layanan terhadap Loyalitas Pelanggan yang Dimediasi oleh Kepuasan Pelanggan 
Tabel 11.

Hasil Analisis Jalur Persamaan Regresi 1

\begin{tabular}{|c|c|c|c|c|c|}
\hline \multirow[t]{3}{*}{ Model } & $\begin{array}{l}\text { Unstandardized } \\
\text { Coefficients }\end{array}$ & $\begin{array}{c}\text { Standardized } \\
\text { Coefficients }\end{array}$ & & \multirow[b]{3}{*}{$\mathbf{T}$} & \multirow[b]{3}{*}{ Sig. } \\
\hline & \multicolumn{3}{|c|}{$\begin{array}{l}\text { Std. } \\
\text { Error }\end{array}$} & & \\
\hline & B & & Beta & & \\
\hline 1 (Constant) & 0,000 & 0,066 & & 0,000 & 1,000 \\
\hline $\begin{array}{l}\text { REGR Factor } \\
\text { Score X }\end{array}$ & 0,752 & 0,067 & 0,752 & 11,293 & 0,000 \\
\hline$: 0,565$ & & & & & \\
\hline F Statistik & & & & & \\
\hline$: 0,000$ & & & & & \\
\hline
\end{tabular}

Sumber : Data Diolah, 2017

Berdasarkan hasil analisis jalur substruktur 1 pada Tabel 11. tersebut, maka dapat disusun persamaan struktur sebagai berikut :

$$
\begin{aligned}
& M=\beta_{1} X+e_{1} \\
& M=0,565 X+e_{1}
\end{aligned}
$$

Tabel 12.

Hasil Analisis Jalur Persaman Regresi 2

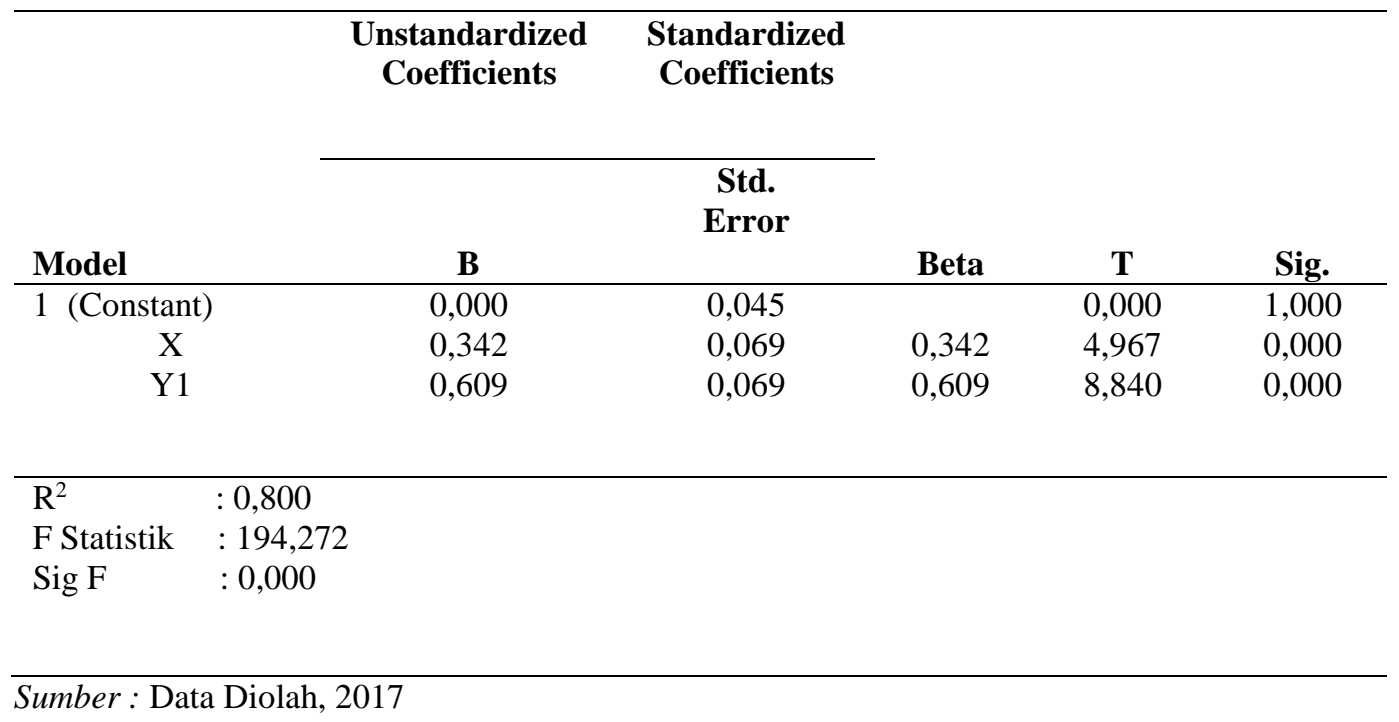

Berdasarkan analisis substruktur 2 pada Tabel 12. tersebut, maka dapat disusun persamaan struktur sebagai berikut : 
$\mathrm{Y}=\beta_{2} \mathrm{X}+\beta_{3} \mathrm{Y}+\mathrm{e}_{2}$

$\mathrm{Y}=0,342 \mathrm{X}+0,609 \mathrm{Y}+\mathrm{e}_{2}$

Kemudian di peroleh nilai koefisien determinasi (R2) dan variabel error (e). Berdasarkan model substruktur 1 dan substruktur 2, maka dapat disusun model diagram jalur akhir. Sebelum menyusun model diagram jalur akhir, terlebih dahulu dihitung nilai standar error sebagai berikut :

$\mathrm{e}=\sqrt{1-\mathrm{R} 1}^{2}$

$\mathrm{e}_{1}={\sqrt{1-R 1^{2}}}^{2}=\sqrt{1-0,565}=0,659$

$\mathrm{e} 2=\sqrt{1-R 2}^{2}=\sqrt{1-0,800}=0,447$

Berdasarkan perhitungan pengaruh error (e), didapatkan hasil pengaruh error $\left(\mathrm{e}_{1}\right)$ sebesar 0,659 dan pengaruh error $\left(\mathrm{e}_{2}\right)$ sebesar 0,447. Hasil koefisien determinasi total adaah sebagai berikut :

$$
\begin{aligned}
\mathrm{R}^{2} \mathrm{~m} & =1-\left(\mathrm{Pe}_{1}\right)^{2}\left(\mathrm{Pe}_{2}\right)^{2} \\
& =1-(0,659)^{2}(0,447)^{2} \\
& =1-(0,434)(0,199) \\
& =1-0,086=0,914
\end{aligned}
$$

Nilai determinasi total sebesar 0,914 mempunyai arti bahwa sebesar 91,4\% variasi loyalitas pelanggan dipengaruhi oleh variasi kualitas layanan dan kepuasan pelanggan, sedangkan sisanya sebesar $8,6 \%$ dijelaskan oleh faktor lain yang tidak dimasukkan ke dalam model 


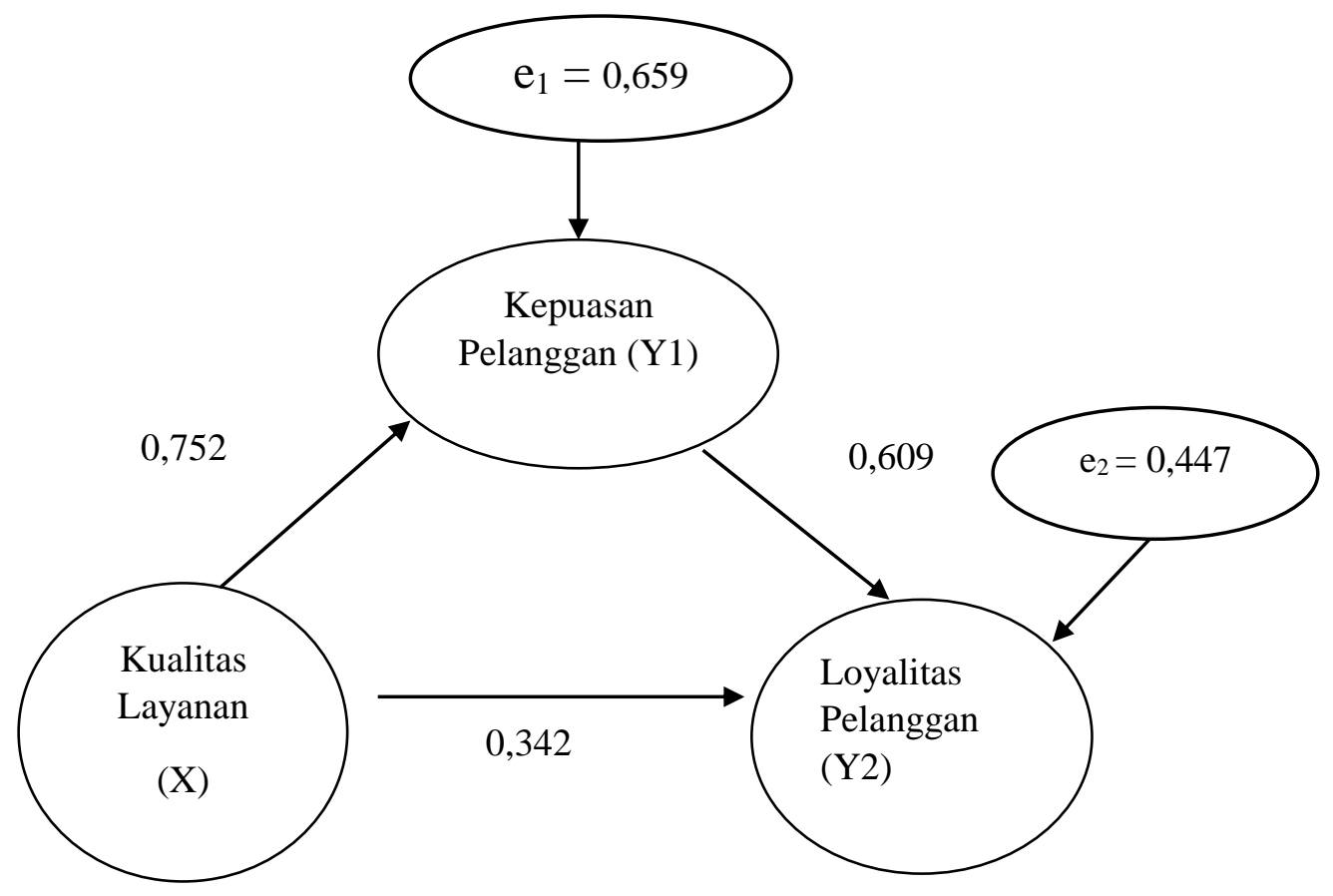

Gambar 3

Validasi Model Diagram Jalur Akhir

Berdasarkan diagram jalur pada Gambar 3. maka dapat dihitung besarnya pengaruh langsung, pengaruh tidak langsung serta pengaruh total antar variabel.

Perhitungan pengaruh antar variabel dirangkum dalam Tabel 13. sebagai berikut:

Tabel 13.

Pengaruh Langsung, Pengaruh Tidak Langsung serta Pengaruh Total Kualitas Layanan (X), Kepuasan Pelanggan (Y1) dan Loyalitas Pelanggan (Y2)

\begin{tabular}{cccc}
\hline $\begin{array}{c}\text { Pengaruh } \\
\text { Variabel }\end{array}$ & Pengarung Langsung & $\begin{array}{c}\text { Pengaruh Tidak } \\
\text { Langsung melalui } \\
\text { Kepuasan Pelanggan } \\
(\text { Y1 })=(\boldsymbol{\beta 1} \mathbf{~} \boldsymbol{\beta 3})\end{array}$ & Pengaruh Total \\
\hline $\mathrm{X} \rightarrow \mathrm{Y} 1$ & 0,752 & - & 0,752 \\
$\mathrm{X} \rightarrow \mathrm{Y} 2$ & 0,342 & 0,457 & 0,799 \\
$\mathrm{Y} 1 \rightarrow$ Y2 & 0,609 & - & 0,609 \\
\hline
\end{tabular}

Sumber : Data Diolah, 2017

Tabel 13. menunjukkan bahwa pengaruh langsung antara variabel kualitas layanan dan kepuasan pelanggan memiliki nilai pengaruh langsung sebesar 0,752 . Dan antara kualitas layanan dengan loyalitas pelanggan dengan nilai pengaruh 
langsung sebesar 0,342 sedangkan nilai pengaruh tidak langsung melalui kepuasan pelanggan sebesar 0,457 dengan nilai pengaruh total sebesar 0,799. Dan yang terakhir nilai pengaruh langsung antara kepuasan pelanggan dan loyalitas pelanggan sebesar 0,609 .

\section{Hasil Uji Sobel}

Uji Sobel merupakan alat analisis untuk menguji hubungan tidak langsung antara variabel independen dengan variabel dependen yang dimediasi oleh variabel yang berperan sebagai mediator. Uji Sobel dirumuskan dengan persamaan berikut dan dapat dihitung dengan menggunakan aplikasi Microsoft Excel. Bila nilai kalkulasi Z lebih besar dari 1,96 (dengan tingkat kepercayaan 95 persen), maka variabel mediasi dinilai secara signifikan memediasi hubungan antara variabel eksogen dan variabel endogen

$\mathrm{Z}=\frac{a b}{\sqrt{b^{2} S a^{2}+a^{2} S b^{2}+S a^{2} S b^{2}}}$

Keterangan :

$$
\begin{array}{ll}
\mathrm{a} & =0,752 \\
\mathrm{~b} & =0,609 \\
\mathrm{Sa} & =0,067 \\
\mathrm{Sb} & =0,069 \\
\mathrm{Z} & =\frac{(0,752) \cdot(0,609)}{\sqrt{(0,609)^{2} \cdot(0,067)^{2}+(0,752)^{2} \cdot(0,069)^{2}+(0,067)^{2} \cdot(0,069)^{2}}} \\
\mathrm{Z}=\frac{(0,457968)}{\sqrt{(0,001)+(0,002)+(0,000021)}} \\
\mathrm{Z}=8,33147
\end{array}
$$


Berdasarkan perhitungan yang telah dilakukan tersebut, diperoleh nilai Z sebesar 8,33147 > 1,96. Ini berarti bahwa variabel mediasi yaitu kepuasan pelanggan dinilai dapat memediasi pengaruh kualitas layanan terhadap loyalitas pelanggan jasa ekspedisi Tiki di Kota Denpasar.

\section{Pengaruh kualitas layanan terhadap kepuasan pelanggan}

Penelitian ini dilakukan untuk mengetahui pengaruh kualitas layanan terhadap kepuasan pelanggan. Hasil olah data menunjukkan nilai koefisien beta sebesar 0,752 dengan tingkat signifikansi $0,000(\leq 0,05)$, artinya $\mathrm{H}_{1}$ yang menyatakan kualitas layanan berpengaruh positif dan signifikan terhadap kepuasan pelanggan pada pada pengguna jasa ekespedisi Tiki dapat diterima. Hasil ini juga dapat diartikan bahwa kegiatan kualitas pelayanan yang dilaksanakan oleh Tiki dapat memperkuat kepuasan pelanggan yang dimiliki oleh Tiki itu sendiri. Peningkatan pelayanan ini harus ditingkatkan dan dipertahankan oleh Tiki untuk menarik konsumen ditahun selanjutnya.

\section{Pengaruh kualitas layanan terhadap loyalitas pelanggan}

Pengaruh selanjutnya yang diteliti dalam penelitian ini adalah pengaruh antara variabel kualitas layanan terhadap loyalitas pelanggan. Hasil olah data menunjukkan nilai koefisien beta sebesar 0,342 dengan tingkat signifikansi 0,000 $(\leq 0,05)$, artinya $\mathrm{H}_{1}$ yang menyatakan kualitas layanan berpengaruh positif dan signifikan terhadap loyalitas pelanggan pada pada pengguna jasa ekspedisi Tiki dapat diterima. Hasil ini juga dapat diartikan bahwa pelayanan yang dilaksanakan oleh Tiki dapat merangsang langsung para konsumen untuk loyal pada jasa ekspedisi Tiki ini. Kegiatan pelayanan yang dilakukan oleh Tiki selain dapat 
meningkatkan kepuasan yang dimiliki pelanggan ternyata juga mampu mempengaruhi langung tingkat keloyalan konsumen di Kota Denpasar.

\section{Pengaruh kepuasan pelanggan terhadap loyalitas pelanggan}

Pengaruh selanjutnya yang diteliti dalam penelitian ini adalah pengaruh antara variabel kepuasan pelanggan terhadap loyalitas pelanggan. Hasil olah data menunjukkan nilai koefisien beta sebesar 0,609 dengan tingkat signifikansi 0,000 $(\leq 0,05)$, artinya $\mathrm{H}_{1}$ yang menyatakan kepuasan pelanggan berpengaruh positif dan signifikan terhadap loyalitas pelanggan pada pada pengguna jasa ekspedisi Tiki dapat diterima. Hasil ini juga dapat diartikan bahwa kekuatan kepuasan pelanggan dari Tiki dapat mempengaruh tindakan konsumen untuk menjadi loyal pada usaha jasa ekspedisi Tiki di Kota Denpasar.

Pengaruh kualitas layanan terhadap loyalitas pelanggan yang dimediasi oleh

\section{kepusaan pelanggan}

Telah disebutkan bahwa kualitas layanan memiliki pengaruh secara parsial pada variabel kepuasan pelanggan, dan kepuasan pelanggan memiliki pengaruh secara parsial pada variabel loyalitas pelanggan. Penelitian ini dilakukan untuk mengetahui peran kepuasan pelanggan dalam memediasi pengaruh kualitas layanan terhadap loyalitas pelanggan. Pengujian pertama menggunakan hasil uji sobel dimana memperoleh angka $\mathrm{Z}=8,33147>1,96$. Hasil ini memberikan arti bahwa variabel mediasi yaitu kepuasan pelanggan memberikan pengaruh pada hubungan variabel kualitas layanan terhadap loyalitas pelanggan. Melihat dari hasil olah data yang tertera pada Tabel 13. menunjukkan bahwa nilai pengaruh secara tidak langsung $(0,457)$ lebih besar dari nilai pengaruh langsung $(0,342)$, 
hasil ini memberikan arti bahwa pengaruh kepuasan pelanggan didalam memediasi kualitas layanan terhadap loyalitas pelanggan sangatlah besar sehingga membuat pengaruh kualitas layanan terhadap loyalitas pelanggan yang awalnya sebesar $(0,342)$ menjadi $(0,799)$. Hasil di atas memberikan arti bahwa $\mathrm{H}_{4}$ yang menyatakan kepuasan pelanggan dapat memediasi pengaruh kualitas layanan terhadap loyalitas pelanggan pada konsumen yang menggunakan jasa ekspedisi Tiki dapat diterima. Hasil ini berarti semakin baik bagi Tiki untuk meningkatkan layananannya untuk mendapatkan keloyalan dan kepuasan dari konsumen.

\section{SIMPULAN DAN SARAN}

Hasil penelitian ini menunjukkan bahwa kualitas layanan berpengaruh positif dan signifikan terhadap loyalitas pelanggan, kualitas layanan berpengaruh positif dan signifikan terhadap kepuasan pelanggan, kepuasan pelanggan berpengaruh positif dan signifikan terhadap loyalitas pelanggan. Kepuasan pelanggan mampu memediasi pengaruh kualitas layanan terhadap loyalitas pelanggan. Jasa ekspedisi Tiki perlu meningkatkan kembali kualitas layanannya khususnya dalam hal memberikan pelayanan dengan cepat dan maksimal kemudian memberikan perhatian yang lebih kepada pelanggan di ruang tunggu serta lebih baik dalam mengucapkan salam pada setiap pelayanan yang diberikan sehingga nantinya mampu menciptakan loyalitas pelanggan yang lebih baik lagi.

Jadi di harapkan kedepannya jasa ekspedisi Tiki dapat memperbaiki kemampuan dalam meningkatkan pelayanannnya dari segi tangible hingga emphaty. Untuk penelitian selanjutnya hendaknya mampu mengembangkan model penelitian dengan menambahkan variabel-variabel yang memiliki pengaruh 
Marcellus Ivan Novandy, Peran Kepuasan Pelanggan Dalam...

terhadap loyalitas pelanggan, kualitas layanan, kepuasan pelanggan dan didukung dengan teori-teori maupun isu-isu terbaru dan lokasi penelitian diperluas. 


\section{REFERENSI}

Aaker, A. D. 1991. Managing Brand Equity. USA: Maxwell Communication Group of Companies.

Afshar, Asghaar. 2011. Study The Effect of Customer Service and Product Quality on Customer Satisfacion and Loyalty. International Journal of Humanities and Social Science, 1(7), pp. 253-260.

Agus Widarjono. 2010. Analisis Statistika Multivariat Terapan. Edisi pertama. Yogyakarta: UPP STIM YKPN.

Aryani, Dwi dan Ferrina Rosinta. 2010. Pengaruh Kualitas Layanan terhadap Kepuasan Pelanggan dalam Membentuk Loyalitas Pelanggan. Jurnal Ilmu Administrasi dan Organisasi, 17(2), pp. 114-126.

Bloemer dan J. Kasper. 1995. The complex relationship between consumer satisfaction and brand loyalty. Journal of Economic Psychology, 16(2), pp. 19-24.

Bowen, J.T. and Chen, S.L. 2001. The relationship between customer loyalty and customer satisfaction, International Journal of Contemporary Hospitality Management, 13(5), pp.213-7

Delgado-Ballester, E and Munuera-Aleman, J. L. 2001, Brand Trust in the Context Consumer Loyalty, European Journal of Marketing, 35(11), pp. 1238-1258.

Ellitan, L. 2006. Strategi Inovasi dan Kinerja Perusahaan Manufaktur di Indonesia: Pendekatan Model Simultan dan Model Sekuensial . Jurnal Manajemen Vol. 6 (14), pp. 1-22

Ellys, Cornelia S., dan Nancy Veronica S. 2008. Analisa Pengaruh Kualitas Layanan terhadap Loyalitas Pelanggan di Laundry 5 Asec Surabaya, Jurnal Manajemen Perhotelan, 4(2),pp. 45-57.

Fandy Tjiptono, dan Gregorius Chandra. 2005. Manajemen Kualitas Jasa. Yogyakarta: Andi Offset.

Fandy Tjiptono, 2006. Manajemen Jasa. Edisi Kedua. Yogyakarta: Andi Offset.

Fandy Tjiptono, 2007, Strategi Pemasaran. Edisi ke dua. Yogyakarta: Andi Offset.

Fandy Tjiptono, dan Gregorius Chandra. 2011. Service, Quality and Satisfaction, Edisi Ketiga. Yogyakarta: Andi Offset.

Ghozali, Imam, 2013. Aplikasi Analisis Multivariat dengan Program IBM SPSS 21. Edisi 7, Penerbit Universitas Diponegoro, Semarang. 
Gilbert, G.R. 2004, Measuring Customer Satisfaction in The Fast Food Industry: A cross-national Approach. The Journal of Services Marketing.Vol. 18(5),pp.371-383.

Griffin, Jill. 2003. Customer Loyalty : Menumbuhkan Dan Mempertahankan Pelanggan. Jakarta, Airlangga.

Hermawan Kartajaya. 2006. Hermawan Kartajaya on Segmentation Seri 9 Elemen Marketing. Bandung: PT. Mizan Pustaka.

I-Ming Wang and Chich-Jen Shieh. 2006. The Relationship Between Service Quality And Customer Satisfaction : The Example Of CJCU Library. Journal of Information \& Optimization Sciences, 27(1), pp. 193-209

Kotler, Phillip, 2003, Manajemen Pemasaran: Analysis, Perencanaan, Implementasi Dan Pengendalian, Edisi Bahasa Indonesia, Jakarta: Salemba Empat.

Kotler, Philip Dan Garry Amstrong. 2009. Prinsip-Prinsip Pemasaran. Jilid 2 Edisi 12 Jakarta: Erlangga.

Lin, H. H., \& Wang, Y. S., 2006, An examination of the determinants of customer loyalty in mobile commerce contexts, Informastion and Management, 43(11), pp. 271-282.

Lovelock, Christopher H. Dan Lauren K. Wright. 2007. Manajemen Pemasaran Jasa. Jakarta: Indeks.

Malik, Muhammad Ehsan. 2012. Impact of Brand Image, Service Quality and Price on Customer Satisfaction in Pakistan Telecommunication Sector, International Journal of Business and Social Science, 3(23), pp. 222-229.

Oliver, R. L. 1999. Whence customer loyalty?. Journal of Marketing,Vol.63, pp. 33-44.

Primananda, Agustinus. 2010. Faktor-faktor yang mempengaruhi konsumen dalam membeli rumah (Studi Kasus di Perumahan Bukit Semarang Baru, Semarang), Skripsi, Jurusan Manajemen Fakultas Wkonomi Universitas Diponegoro, Diponegoro).

Rahyuda, I K,. I. G. W. Yasa, N. N. Yuliarmi. 2004. Metodologi Penelitian. Diktat Kuliah Fakultas Ekonomi. Denpasar: Universitas Udayana.

Ratih Hardiyati. 2010. Analisis Pengaruh Kualitas Pelayanan Terhadap Kepuasan Konsumen Menggunakan Jasa Penginapan (Villa) Agrowisata Kebun Teh Pagilaran. Skripsi dipublikasikan. Universitas Diponegoro Semarang.

Saha, G.C and Theingi 2009, Service quality, satisfaction, and behavioural intentions A study of low-cost airline carriers in Thailand, Managing Service 
Quality, 19(3), pp. 350-372.

Siddiqi, K.O. 2011. Between Service Quality Attributes, Customer Satisfaction and Customer Loyalty in the Retail Banking Sector in Bangladesh, International Journal of Business and Management, Vol. 6(3), pp. 12 - 36.

Starini, Hygid. 2013. Pengaruh Kualitas Pelayanan terhadap Loyalitas Konsumen dengan Kepuasan sebagai Variabel Mediasi (Studi Pada Toko Basuki JayaYogyakarta). Skripsi Tidak Diterbitkan. Universitas Negeri Yogyakarta.

Sugiyono. 2013. Metode Penelitian Pendidikan Pendekatan Kuantitatif, Kualitatif, dan R\&D. Bandung: Alfabeta.

Sunarto. 2006. Pengantar Manajemen Pemasaran. Cet. 1. Yogyakarta : Ust Press.

Sutomo, Maskuri. 2012. Kepuasan Pelanggan Menginap di Hotel Berbintang di Daerah Istimewa Yogyakarta.Jurnal Bisnis dan Manajemen, 6(1),pp. 79-93.

Yuliastina, Ni Kadek. 2013. Pengaruh Kualitas Pelayanan Terhadap Kepuasan Konsumen Pada L'Amore Café Di Denpasar. Skripsi. Fakultas Ekonomi Dan Bisnis Universitas Udayana.

Zeithaml, V.A. and M.J. Bitner.1996. Services Marketing. The McGraw-Hill Companies, Inc. New York. 
Marcellus Ivan Novandy, Peran Kepuasan Pelanggan Dalam... 